\title{
Kemampuan Membaca Nyaring melalui Model Pembelajaran Pair Check Siswa Kelas VIII SMP Negeri 10 Kota Palopo
}

\section{Suparman ${ }^{1}$}

\author{
Nurfisani ${ }^{2}$ \\ 12 Universitas Cokroaminoto Palopo, Indonesia \\ ${ }^{1}$ suparman@uncp.ac.id \\ 2 nurfisani@yahoo.co.id
}

\begin{abstract}
Abstrak
Penelitian ini bertujuan mendeskripsikan kemampuan membaca nyaring melalui model pembelajaran pair check siswa kelas VIII SMP Negeri 10 Kota Palopo. Penelitian ini merupakan penelitian kuantitatif yang melibatkan satu kelompok. Penelitian ini didesain secara deskriptif. Sampel pada penelitian ini, yaitu siswa kelas VIII.C yang ditentukan secara purposive sampling. Teknik pengumpulan data yang dilakukan dalam penelitian ini adalah observasi, tes, dan dokumentasi. Data hasil penelitian ini dianalisis dengan menggunakan analisis statistik deskriptif. Hasil Hasil penelitian menunjukkan bahwa nilai rata-rata yang diperoleh siswa kelas VIII.C SMP Negeri 10 Kota Palopo dalam membaca nyaring melalui model pembelajaran pair check, yaitu 66,67. Nilai rata-rata tersebut diperoleh dari sampel yang mendapat nilai 89 berjumlah $1(6,7 \%)$; sampel yang mendapat nilai 72 berjumlah $4(26,7 \%)$; sampel yang mendapat nilai 67 berjumlah $4(26,7 \%)$; sampel yang mendapat nilai 61 berjumlah 5 (33,3\%); sampel yang mendapat nilai 61 berjumlah 1 (6,7\%). Apabila dikonfirmasikan dengan KKM, maka kemampuan membaca nyaring melalui model pembelajaran pair check siswa kelas VIII.C SMP Negeri 10 Kota Palopo, yaitu yang mendapat nilai $77 \mathrm{ke}$ atas sebanyak 1 sampel $(6,7 \%)$, sedangkan yang mendapat nilai di bawah 77 sebanyak 14 sampel (93,3\%). Dilihat dari tolok ukur kemampuan, siswa dapat dikatakan tidak mampu karena siswa yang memperoleh nilai di bawah 77 mencapai lebih dari 85\%.
\end{abstract}

Kata kunci: membaca nyaring, pair check

\section{Pendahuluan}

Pembelajaran Bahasa Indonesia bertujuan untuk meningkatkan kemampuan siswa untuk berkomunikasi dengan menggunakan Bahasa Indonesia yang baik dan benar, baik secara lisan maupun tulisan serta menumbuhkan apresiasi terhadap hasil karya sastra Indonesia. Oleh karena itu, untuk mencapai kompetensi hasil belajar Bahasa Indonesia harus dikembangkan melalui empat aspek kemampuan utama Bahasa Indonesia.

Keterampilan berbahasa memiliki empat aspek, yaitu menyimak, berbicara, membaca, dan menulis. Keempat keterampilan berbahasa disajikan secara terpadu, namun dimungkinkan untuk memberikan penekanan pada salah satu keterampilan. Dari keempat 
keterampilan tersebut, keterampilan membaca merupakan keterampilan yang sangat dibutuhkan oleh siswa. Keterampilan membaca merupakan keterampilan yang bersifat reseptif, artinya keterampilan membaca merupakan keterampilan yang menerima.

Setiap proses pembelajaran berbahasa hendaknya lebih diperhatikan agar tepat sasaran dan mampu meningkatkan kemampuan berbahasa siswa. Termasuk di dalamnya adalah keterampilan membaca yang memiliki banyak manfaat dalam perkembangan berbahasa siswa. Melalui kegiatan membaca siswa mampu memperoleh banyak pengetahuan. Oleh sebab itu, guru sebaiknya memiliki perhatian khusus dalam kompetensi membaca ini karena selain manfaatnya yang besar bagi siswa, membaca juga merupakan kegiatan yang kompleks. Kompleks artinya dalam proses membaca terlibat faktor internal dan faktor eksternal pembaca. Faktor internal dapat berupa intelegensi (IQ), minat, sikap, bakat, motivasi, tujuan membaca, dan sebagainya, sedangkan faktor eksternal bisa dalam bentuk sarana membaca, teks bacaan, faktor lingkungan, atau faktor latar belakang sosial ekonomi, kebiasaan, dan tradisi membaca.

Ada beberapa jenis membaca. Salah satu jenis membaca yang baik untuk diterapkan pada siswa, khususnya siswa SMP kelas VIII adalah membaca nyaring. Membaca nyaring merupakan salah satu aspek keterampilan yang harus dikuasai oleh seorang siswa dalam Kurikulum Tingkat Satuan Pendidikan (KTSP). Kompetensi dasar pada KTSP terjabarkan bahwa siswa diharapkan mampu membacakan teks berita dengan intonasi yang tepat serta artikulasi dan volume suara yang jelas. Membaca nyaring merupakan proses mengomunikasikan isi bacaan dengan nyaring kepada orang lain. Membaca nyaring berbeda dengan membaca pemahaman. Membaca nyaring merupakan kegiatan membaca yang menyuarakan tulisan yang dibaca dengan ucapan dan intonasi yang tepat agar pendengar dan pembaca dapat menangkap informasi yang disampaikan oleh penulis, sedangkan membaca dalam hati merupakan kegiatan membaca dengan tidak mengeluarkan kata-kata atau suara agar pembaca dapat berkonsentrasi dan memahami isi yang terkandung dalam bacaan.

Hasil observasi awal yang dilaksanakan di SMP Negeri 10 Kota Palopo, ditemukan bahwa kemampuan siswa kelas VIII dalam menemukan masalah utama dari berbagai berita yang bertopik sama melalui membaca nyaring masih rendah. Hal ini terlihat dari nilai rata-rata siswa pada mata pelajaran bahasa Indonesia, khususnya untuk materi membaca nyaring masih di bawah standar Kriteria Ketuntasan Minimal (KKM) yang telah ditetapkan oleh sekolah. Oleh karena itu, diperlukan strategi pembelajaran yang tepat untuk meningkatkan kemampuan membaca nyaring siswa.

Salah satu strategi yang tepat untuk diterapkan dalam membaca nyaring siswa adalah dengan menerapkan model pembelajaran pair check. Model pembelajaran pair check merupakan salah satu model pembelajaran kooperatif yang menuntut kemandirian dan kemampuan siswa dalam menyelesaikan persoalan. Model pembelajaran pair check mengajak siswa untuk berpasangan dalam kelompok. Setiap pasangan dalam kelompok saling menjawab dan memeriksa pertanyaan.

Berdasarkan uraian di atas, maka peneliti tertarik untuk melakukan penelitian dengan judul "Kemampuan Membaca Nyaring melalui Model Pembelajaran Pair Check Siswa Kelas VIII SMP Negeri 10 Kota Palopo".

Alasan peneliti memilih SMP Negeri 10 Kota Palopo sebagai lokasi untuk melakukan penelitian karena belum ada yang melakukan penelitian di SMP Negeri 10 Kota Palopo dengan menggunakan model pembelajaran pair check, khususnya dalam membaca nyaring. Alasan lainnya adalah karena tiap-tiap kelas di SMP Negeri 10 Kota Palopo memiliki 
karakteristik siswa yang heterogen, sehingga memudahkan peneliti dalam menentukan sampel.

Membaca merupakan suatu kegiatan atau proses kognitif yang berupaya untuk menemukan berbagai informasi yang terdapat dalam tulisan. Hal ini berarti membaca merupakan proses berpikir untuk memahami isi teks yang dibaca. Oleh sebab itu, membaca bukan hanya sekadar melihat kumpulan huruf yang telah membentuk kata, kelompok kata, kalimat, paragraf, dan wacana saja, tetapi lebih dari itu, membaca merupakan kegiatan memahami dan menginterpretasikan lambang/tanda/tulisan yang bermakna, sehingga pesan yang disampaikan penulis dapat diterima oleh pembaca.

Menurut Kamus Besar Bahasa Indonesia (Phoenix, 2013:94), membaca adalah 1) melihat serta memahami isi dari apa yang tertulis (dengan melisankan atau hanya dalam hati); 2) mengeja atau melafalkan apa yang tertulis. Farr (dalam Dalman, 2014:5) mengemukakan "reading is the heart of education" yang artinya membaca merupakan jantung pendidikan. Orang yang sering membaca, pendidikannya akan maju dan akan memiliki wawasan yang luas. Tentu saja hasil membacanya itu akan menjadi skemata baginya. Skemata ini adalah pengetahuan dan pengalaman yang dimiliki seseorang. Jadi, semakin sering seseorang membaca, maka semakin besarlah peluang mendapatkan skemata dan berarti semakin maju pulalah pendidikannya. Hal inilah yang melatarbelakangi banyak orang yang mengatakan bahwa membaca sama dengan membuka jendela dunia. Saat membaca kita dapat mengetahui seisi dunia dan pola berpikir kita pun akan berkembang.

Berbeda dengan pendapat di atas, Anderson (dalam Dalman, 2014:6) rnenjelaskan bahwa membaca adalah suatu proses penyandian kembali dan pembacaan sandi ( $a$ recording and decoding process). Istilah penyandian kembali (recording) digunakan untuk gantikan istilah membaca (reading) karena mula-mula lamban tertulis diubah menjadi bunyi, baru kemudian sandi itu dibaca, sedangkan pembacaan sandi (decoding process) merupakan suatu penafsiran atau interpretasi terhadap ujaran dalam bentuk tulisan. Jadi, membaca itu merupakan proses membaca sandi berupa tulisan yang harus diinterpretasikan maksudnya, sehingga apa yang ingin disampaikan oleh penulisnya dapat dipahami dengan baik.

Menurut Harjasujana dan Mulyati (dalam Dalman, 2014:6), membaca merupakan perkernbangan keterampilan yang bermula dari kata dan berlanjut kepada membaca kritis. Damaianti (dalam Dalman, 2014:6) rnengemukakan bahwa membaca merupakan hasil interaksi antara persepsi terhadap lambang-lambang yang mewujudkan bahasa melalui keterampilan berbahasa yang dimiliki pembaca dan pengetahuannya tentang alam sekitar.

Sejalan dengan beberapa pendapat di atas, Klein dkk., (dalam Rahim, 2005:3) mengemukakan bahwa membaca mencakup 1) membaca merupakan suatu proses. Maksudnya adalah informasi dari teks atau pengetahuan yang dimiliki oleh pembaca memunyai peranan yang utama dalam membentuk makna, 2) membaca adalah strategis. Pembaca yang efektif menggunakan berbagai strategi membaca yang sesuai dengan teks dan konteks dalam rangka mengonstruk makna ketika membaca, dan 3) membaca interaktif. Keterlibatan pembaca dengan teks tergantung pada konteks. Orang yang senang membaca suatu teks yang bermanfaat, akan menemukan beberapa tujuan yang ingin dicapainya, teks yang dibaca seseorang harus mudah dipahami (readable), sehingga terjadi interaksi antara pembaca dan teks.

Tarigan (dalam Dalman 2014:7) mengemukakan bahwa membaca adalah suatu proses yang dilakukan serta dipergunakan oleh pembaca untuk memperoleh pesan yang hendak disampaikan oleh penulis melalui media kata-kata/bahasa tulis. Membaca adalah suatu usaha untuk menelusuri makna yang ada dalam tulisan. Membaca merupakan proses 
memahami kata dan memadukan arti kata dalam kalimat dan struktur bacaan, sehingga pembaca mampu memahami isi teks yang dibacanya dan pada akhirnya dapat merangkum isi bacaan tersebut dengan menggunakan bahasa sendiri.

Berdasarkan beberapa definisi tentang membaca yang telah disampaikan para ahli, maka dapat disimpulkan bahwa membaca adalah proses perubahan bentuk lambang/tanda/tulisan menjadi wujud bunyi yang bermakna. Oleh sebab itu, kegiatan membaca ini sangat ditentukan oleh kegiatan fisik dan mental yang menuntut seseorang untuk menginterpretasikan simbol-simbol tulisan dengan aktif dan kritis sebagai pola komunikasi dengan diri sendiri, agar pembaca dapat menemukan makna tulisan dan memperoleh informasi yang dibutuhkan.

Model pembelajaran pair check merupakan model pembelajaran berkelompok antardua orang atau berpasangan yang dipopulerkan oleh Spencer Kagan (1990). Model ini menerapkan pembelajaran kooperatif yang menuntut kemandirian dan kemampuan siswa dalam menyelesaikan persoalan. Metode ini juga melatih tanggung jawab sosial siswa, kerja sama, dan kemampuan memberi penilaian (Huda, 2015: 211).

Langkah-langkah model pembelajaran pair check menurut Huda (2015:211) adalah sebagai berikut:

1) Guru menjelaskan konsep.

2) Siswa dibagi ke dalam beberapa tim. Setiap tim terdiri dari 4 orang. Dalam satu tim ada 2 pasangan. Setiap pasangan dalam satu tim dibebani masing-masing satu peran yang berbeda: pelatih dan partner.

3) Guru membagikan soal kepada partner.

4) Partner menjawab soal dan si pelatih mengecek jawabannya. Partner yang menjawab satu soal dengan benar berhak mendapat satu kupon dari pelatih.

5) Pelatih dan partner saling bertukar peran. Pelatih menjadi partner dan partner menjadi pelatih.

6) Guru membagikan soal kepada partner.

7) Partner menjawab soal dan si pelatih mengecek jawabannya. Partner yang menjawab satu soal dengan benar berhak mendapat satu kupon dari pelatih.

8) Setiap pasangan kembali ke tim awal dan mencocokkan jawaban satu sama lain.

9) Guru membimbing dan memberikan arahan atas jawaban dari berbagai soal.

10) Setiap tim mengecek jawabannya.

11) Tim yang paling banyak mendapatkan kupon diberi hadiah atau reward oleh guru. 


\section{Metode}

\section{Jenis Penelitian}

Penelitian ini merupakan jenis penelitian kuantitatif yang bersifat deskriptif. Penelitian ini berusaha menggambarkan kemampuan membaca nyaring siswa melalui model pembelajaran pair check.

\section{Populasi dan Sampel}

\section{Populasi}

Populasi adalah wilayah generalisasi yang terdiri atas objek/subjek yang mempunyai kualitas dan karakteristik tertentu yang ditetapkan oleh peneliti untuk dipelajari dan kemudian ditarik kesimpulannya (Sugiyono, 2014:117). Populasi dalam penelitian ini adalah seluruh siswa kelas VIII SMP Negeri 10 Kota Palopo. Untuk lebih jelasnya, dapat dilihat pada tabel di bawah ini.

Tabel 1. Keadaan populasi

\begin{tabular}{ccccc}
\hline \multirow{2}{*}{ No. } & Kelas & \multicolumn{2}{c}{ Jenis Kelamin } & Jumlah \\
\cline { 3 - 4 } & & Laki-laki & Perempuan & \\
\hline 1 & VIII.A & 13 & 8 & 21 \\
2 & VIII.B & 10 & 11 & 21 \\
3 & VIII.C & 8 & 12 & 20 \\
4 & VIII.D & 9 & 9 & 18 \\
\hline & Jumlah & 40 & 40 & 80 \\
\hline
\end{tabular}

Sumber: Tata usaha SMP Negeri 10 Kota Palopo (2017)

\section{Sampel}

Teknik pengambilan sampel yang peneliti gunakan, yaitu teknik purposive sampling. Mengenai hal ini, Sugiyono (2014:124) menjelaskan bahwa purposive sampling adalah teknik penentuan sampel dengan pertimbangan tertentu. Sampel pada penelitian ini adalah siswa kelas VIII.C SMP Negeri 10 Kota Palopo. Peneliti memilih kelas VIII.C SMP Negeri 10 Kota Palopo sebagai sampel karena siswa memiliki karakteristik sama/heterogen, baik dari tingkat kemampuan siswa, ras, jenis kelamin, dan agama.

\section{Teknik Pengumpulan Data}

\section{Observasi}

Observasi adalah melakukan pengamatan langsung terhadap objek kajian guna mengumpulkan data-data dan diperoleh informasi yang dibutuhkan. Teknik observasi yang dilakukan pada penelitian ini adalah observasi langsung dengan tujuan untuk menentukan waktu yang tepat melaksanakan penelitian, mengumpulkan data dan informasi.

\section{Tes}

Menurut Arikunto (2008:53) tes merupakan alat atau prosedur yang digunakan untuk mengetahui atau mengukur sesuatu dalam suasana, dengan cara dan aturan-aturan yang sudah ditentukan. Pada penelitian ini, teknik pengumpulan data, yaitu dengan tes kemampuan membaca nyaring siswa. 


\section{Dokumentasi}

Dokumentasi adalah suatu teknik mencari data mengenai hal-hal atau variabel yang berupa catatan, transkrip, buku, surat kabar, majalah, prasasti, notulen rapat, lengger, agenda, dan sebagainya (Arikunto, 2006:231). Dokumentasi digunakan untuk memperoleh data nama-nama siswa, jumlah siswa dan data lain yang digunakan untuk kepentingan penelitian.

\section{Teknik Analisis Data}

Teknik analisis data yang digunakan dalam penelitian ini, yaitu analisis statistik deskriptif. Statistik deskriptif digunakan untuk mendeskripsikan karakteristik responden. Pengelolaan data dan teknik prosedur sebagai berikut:

1. Membuat daftar skor mentah.

2. Menentukan nilai baku setiap sampel dengan menggunakan rumus:

$$
\text { Nilai }=\frac{\text { Jumlah Skor Siswa }}{\text { Jumlah Skor Maksimal }} \times 100
$$

3. Menentukan frekuensi dan persentase nilai yang dicapai.

4. Menentukan nilai rata-rata kemampuan siswa.

5. Menentukan kategori interval nilai siswa.

Tabel 2. Kategori interval nilai

\begin{tabular}{lllll}
\hline No. & Interval Nilai & Kategori & Frekuensi & Persentase (\%) \\
\hline 1 & $85-100$ & Sangat baik & \\
2 & $77-84$ & Baik & \\
3 & $66-76$ & Cukup & \\
4 & $55-65$ & Kurang & \\
5 & $0-54$ & Sangat kurang & \\
\hline & & Jumlah & \\
\hline
\end{tabular}

Sumber: SMP Negeri 10 Kota Palopo (2017)

6. Memberikan interpretasi terhadap kemampuan siswa.

Tabel 3. Hasil pencapaian KKM siswa

\begin{tabular}{llll}
\hline No. & Perolehan Nilai & Frekuensi & Persentase (\%) \\
\hline 1 & Nilai $\geq 77$ & \\
2 & Nilai $<77$ & \\
\hline & Jumlah & \\
\hline
\end{tabular}

Sumber: SMP Negeri 10 Kota Palopo (2017)

7. Tolok ukur kemampuan siswa, yakni jika $85 \%$ dari jumlah siswa memperoleh nilai $\geq 77$, maka dianggap mampu. Tetapi, jika $85 \%$ dari jumlah siswa memperoleh nilai $<77$, maka dianggap tidak mampu.

8. Rubrik penilaian dalam membaca nyaring.
a. Kejelasan ucapan (ketepatan pemenggalan kata dalam kalimat)
b. Intonasi (variasai irama dan tekanan)
c. Pelafalan (ketepatan melafalkan kata)
d. Suara
e. Sikap
f. Penampilan 


\section{Hasil}

Hasil penelitian ini bertujuan mendeskripsikan kemampuan membaca nyaring melalui model pembelajaran pair check siswa kelas VIII SMP Negeri 10 Kota Palopo. Pada penelitian ini, sampel yang akan diteliti berjumlah 20 siswa, namun sampel yang hadir pada saat tes hanya berjumlah 15 siswa. Data hasil penelitian ini berupa data kuantitatif. Data yang diperoleh dalam penelitian ini, diolah dan dianalisis berdasarkan teknik dan prosedur yang telah ditentukan sebelumnya. Langkah pertama dalam menganalisis data adalah membuat daftar skor mentah yang diperoleh sampel.

Tabel 4. Distribusi frekuensi skor mentah

\begin{tabular}{lll}
\hline No. & Skor & Frekuensi \\
\hline 1 & 16 & 1 \\
2 & 13 & 4 \\
3 & 12 & 4 \\
4 & 11 & 5 \\
5 & 9 & 1 \\
\hline & Jumlah & 15 \\
\hline & & Sumber: Data primer
\end{tabular}

Sumber: Data primer (2017)

Tabel 4 menunjukkan bahwa dari 15 sampel, skor tertinggi yang diperoleh sampel adalah 16, sedangkan skor terendah adalah 9. Skor 16 diperoleh 1 sampel; skor 13 diperoleh 4 sampel; skor 12 diperoleh 4 sampel; skor 11 diperoleh 5 sampel; skor 9 diperoleh 1 sampel. Langkah selanjutnya, membuat daftar distribusi frekuensi skor mentah ke dalam nilai baku dengan ketentuan:

$$
\text { Nilai }=\frac{\text { Jumlah Skor Siswa }}{\text { Jumlah Skor Maksimal }} \times 100
$$

Tabel 5. Distribusi frekuensi skor mentah ke dalam nilai baku

\begin{tabular}{lllll}
\hline No. & Skor & Nilai & Frekuensi & Persentase (\%) \\
\hline 1 & 16 & 89 & 1 & 6,7 \\
2 & 13 & 72 & 4 & 26,7 \\
3 & 12 & 67 & 4 & 26,7 \\
4 & 11 & 61 & 5 & 33,3 \\
5 & 9 & 50 & 1 & 6,7 \\
\hline & Jumlah & & 15 & 100 \\
\hline
\end{tabular}

Sumber: Data primer setelah diolah (2017)

Tabel 5 menunjukkan bahwa nilai yang diperoleh sampel bervariasi. Sampel yang memperoleh skor 16 mendapat nilai 89 berjumlah 1 (6,7\%); sampel yang memperoleh skor 13 mendapat nilai 72 berjumlah $4(26,7 \%)$; sampel yang memperoleh skor 12 mendapat nilai 67 berjumlah 4 (26,7\%); sampel yang memperoleh skor 11 mendapat nilai 61 berjumlah 5 (33,3\%); sampel yang memperoleh skor 9 mendapat nilai 61 berjumlah $1(6,7 \%)$.

Tabel 6. Distribusi frekuensi dan persentase nilai kemampuan membaca nyaring melalui model pembelajaran pair check siswa kelas VIII.C SMP Negeri 10 Kota Palopo

\begin{tabular}{llll}
\hline No. & Nilai & Frekuensi & Persentase (\%) \\
\hline 1 & 89 & 1 & 6,7 \\
2 & 72 & 4 & 26,7 \\
3 & 67 & 4 & 26,7 \\
4 & 61 & 5 & 33,3 \\
5 & 50 & 1 & 6,7
\end{tabular}




\begin{tabular}{ccc}
\hline Jumlah & 15 & 100 \\
\hline & & Sumber: Data primer setelah diolah (2017)
\end{tabular}

Tabel 6 menunjukkan bahwa nilai yang diperoleh sampel bervariasi. Sampel yang mendapat nilai 89 berjumlah $1(6,7 \%)$; sampel yang mendapat nilai 72 berjumlah $4(26,7 \%)$; sampel yang mendapat nilai 67 berjumlah 4 (26,7\%); sampel yang mendapat nilai 61 berjumlah 5 (33,3\%); sampel yang mendapat nilai 61 berjumlah $1(6,7 \%)$.

Tabel 7. Perolehan nilai rata-rata kemampuan membaca nyaring melalui model pembelajaran pair check siswa kelas VIII.C SMP Negeri 10 Kota Palopo

\begin{tabular}{|c|c|c|c|c|}
\hline No. & Nilai (X) & Frekuensi (N) & Jumlah Nilai ( $\sum$ VIII.C) & $\frac{\sum \mathrm{VIII} . \mathrm{C}}{\mathrm{N}}$ \\
\hline 1 & 89 & 1 & 89 & \\
\hline 2 & 72 & 4 & 288 & \\
\hline 3 & 67 & 4 & 268 & $1.000 / 15$ \\
\hline 4 & 61 & 5 & 305 & \\
\hline \multirow[t]{2}{*}{5} & 50 & 1 & 50 & \\
\hline & Jumlah & 15 & 1.000 & 66,67 \\
\hline
\end{tabular}

Tabel 7 menunjukkan bahwa nilai rata-rata kemampuan membaca nyaring melalui model pembelajaran pair check siswa kelas VIII.C SMP Negeri 10 Kota Palopo adalah 66,67 yang diperoleh dari jumlah seluruh nilai ( $\Sigma$ VIII.C) dibagi dengan jumlah sampel $(N)$ atau $\sum$ VIII.C/N $=1.000 / 15=66,67$.

Tabel 8. Kategori interval nilai siswa kelas VIII.C SMP Negeri 10 Kota Palopo

\begin{tabular}{ccccc}
\hline No. & Interval Nilai & Kategori & Frekuensi & Persentase (\%) \\
\hline 1 & $85-100$ & Sangat baik & 1 & 6,7 \\
2 & $77-84$ & Baik & - & - \\
3 & $66-76$ & Cukup & 8 & 53,3 \\
4 & $55-65$ & Kurang & 5 & 33,3 \\
5 & $0-54$ & Sangat kurang & 1 & 6,7 \\
\hline & & Jumlah & 15 & 100 \\
\hline
\end{tabular}

Sumber: Data primer setelah diolah (2017)

Tabel 8 menunjukkan bahwa tingkat kemampuan membaca nyaring melalui model pembelajaran pair check siswa kelas VIII.C SMP Negeri 10 Kota Palopo berada pada kategori sangat baik yang diperoleh 1 sampel (6,7\%); pada kategori cukup yang diperoleh 8 sampel (53,3\%); pada kategori kurang yang diperoleh 5 sampel (33,3\%); pada kategori sangat kurang yang diperoleh 1 sampel (6,7\%) Tidak ada sampel yang berada pada kategori baik. Untuk lebih jelasnya, lihat diagram berikut.

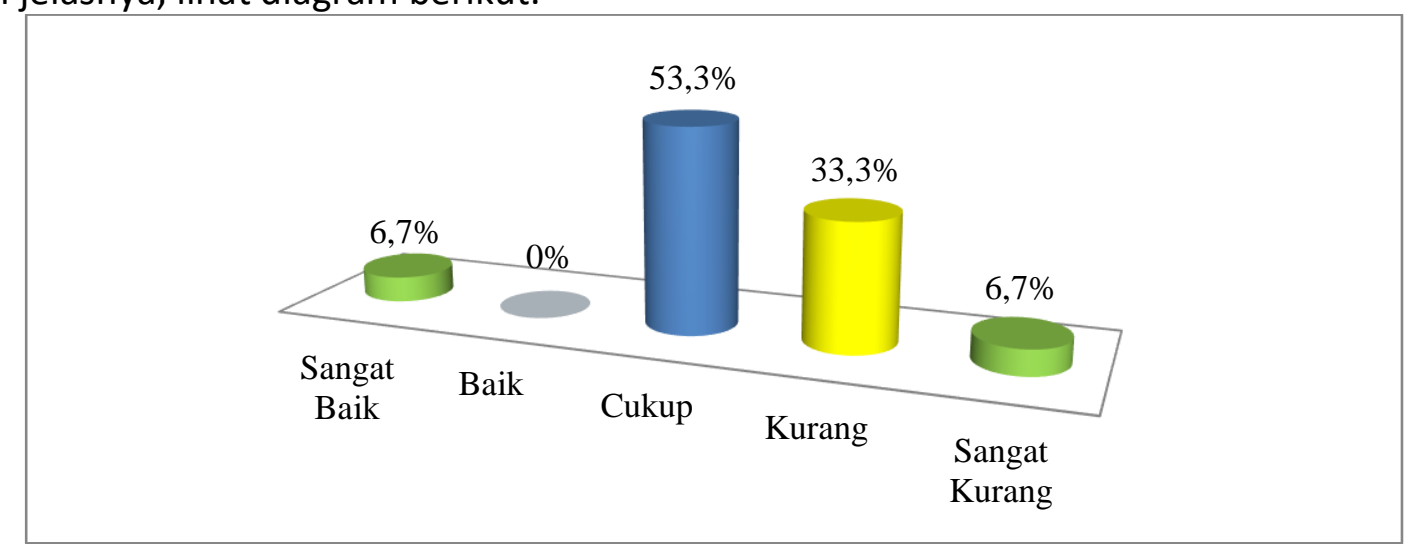


Gambar 2. Kategori interval nilai siswa kelas VIII.C SMP Negeri 10 Kota Palopo

Tabel 9. Hasil pencapaian KKM siswa kelas VIII.C SMP Negeri 10 Kota Palopo

\begin{tabular}{cccc}
\hline No. & Perolehan Nilai & Frekuensi & Persentase (\%) \\
\hline 1 & Nilai $\geq 77$ & 1 & 6,7 \\
2 & Nilai $<77$ & 14 & 93,3 \\
\hline & Jumlah & 15 & 100 \\
\hline
\end{tabular}

Sumber: Data primer setelah diolah (2017)

Tabel 9 menunjukkan bahwa hasil pencapaian KKM dalam membaca nyaring melalui model pembelajaran pair check siswa kelas VIII.C SMP Negeri 10 Kota Palopo, yaitu yang mendapat nilai 77 ke atas sebanyak 1 sampel $(6,7 \%)$, sedangkan yang mendapat nilai di bawah 77 sebanyak 14 sampel (93,3\%). Dengan demikian, dapat dikatakan bahwa tingkat kemampuan membaca nyaring melalui model pembelajaran pair check siswa kelas VIII.C SMP Negeri 10 Kota Palopo dapat dikatakan tidak mampu apabila dikonfirmasikan dengan nilai KKM sekolah pada mata pelajaran bahasa Indonesia, yaitu siswa dinyatakan tidak mampu apabila siswa yang memperoleh nilai di bawah 77 mencapai 85\%. Untuk lebih jelasnya, dapat dilihat pada diagram berikut.

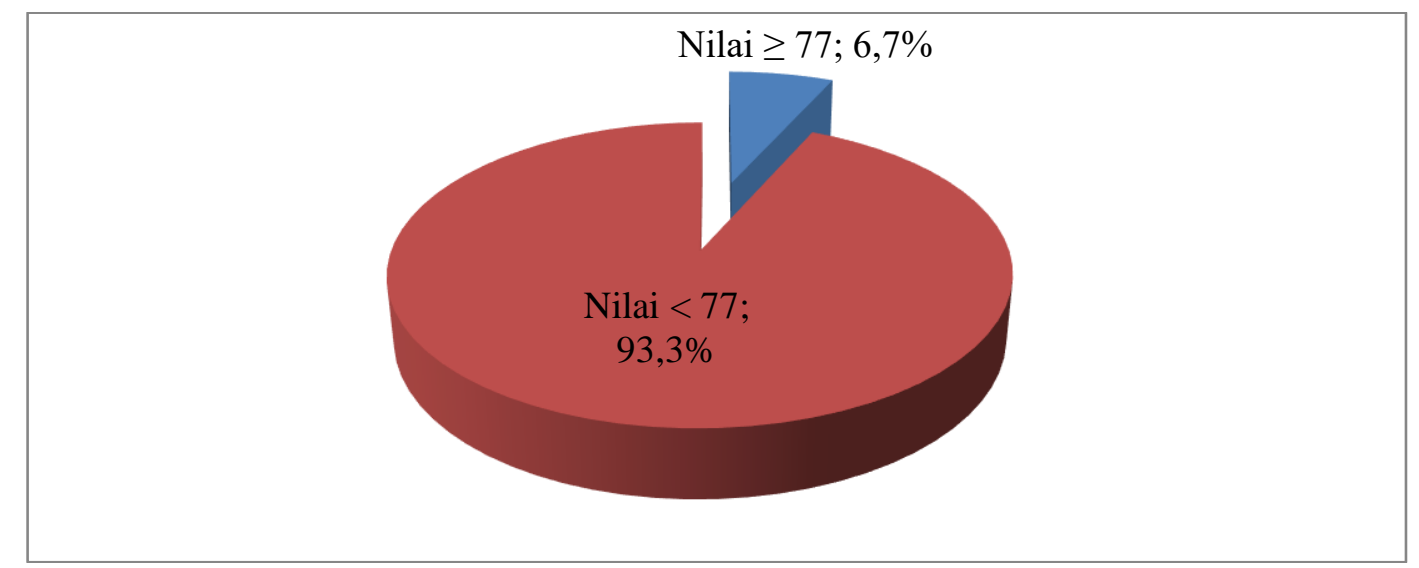

Gambar 3. Hasil pencapaian KKM siswa kelas VIII.C SMP Negeri 10 Kota Palopo

\section{Pembahasan}

Hasil penelitian yang diuraikan pada bagian ini, menyajikan hasil temuan yang diperoleh melalui penelitian. Sesuai dengan judul penelitian ini, yaitu "Kemampuan Membaca Nyaring melalui Model Pembelajaran Pair Check Siswa Kelas VIII SMP Negeri 10 Kota Palopo," maka ada dua hal pokok yang penting diketahui oleh siswa, yaitu membaca nyaring dan model pembelajaran pair check. Membaca nyaring adalah kegiatan membaca dengan menyuarakan tulisan yang dibacanya dengan ucapan dan intonasi yang tepat agar pendengar dan pembaca dapat menangkap informasi yang disampaikan oleh penulis, baik yang berupa pikiran, perasaan, sikap, ataupun pengalaman penulis. Model pembelajaran pair check adalah salah satu model pembelajaran kooperatif yang mengajak siswa untuk berpasangan di dalam kelompok, kemudian setiap pasangan dalam kelompok akan saling memberikan pertanyaan dan memeriksa jawaban dari pertanyaan yang diberikan.

Hasil data temuan memperlihatkan bahwa hasil belajar siswa setelah diadakan tes diperoleh nilai rata-rata 66,67 dari 15 sampel. Nilai rata-rata tersebut diperoleh dari sampel 
yang mendapat nilai 89 berjumlah $1(6,7 \%)$; sampel yang mendapat nilai 72 berjumlah 4 (26,7\%); sampel yang mendapat nilai 67 berjumlah 4 (26,7\%); sampel yang mendapat nilai 61 berjumlah 5 (33,3\%); sampel yang mendapat nilai 61 berjumlah $1(6,7 \%)$.

Hasil temuan yang didapatkan dari tes tersebut, diketahui bahwa hasil pencapaian KKM dalam membaca nyaring melalui model pembelajaran pair check siswa kelas VIII.C SMP Negeri 10 Kota Palopo, yaitu yang mendapat nilai 77 ke atas sebanyak 1 sampel $(6,7 \%)$, sedangkan yang mendapat nilai di bawah 77 sebanyak 14 sampel (93,3\%). Dengan demikian, dapat dikatakan bahwa tingkat kemampuan membaca nyaring melalui model pembelajaran pair check siswa kelas VIII.C SMP Negeri 10 Kota Palopo dapat dikatakan tidak mampu apabila dikonfirmasikan dengan nilai KKM sekolah pada mata pelajaran bahasa Indonesia, yaitu siswa dinyatakan tidak mampu apabila siswa yang memperoleh nilai di bawah 77 mencapai $85 \%$.

Hasil pengamatan secara subjektif, kemampuan membaca nyaring melalui model pembelajaran pair check siswa kelas VIII.C SMP Negeri 10 Kota Palopo dipengaruhi oleh pendidik atau peneliti dalam menyampaikan materi ajar, cara siswa dalam memahami materi yang diajarkan pendidik atau peneliti, yaitu tentang konsep membaca nyaring yang merupakan konsep dasar yang perlu diketahui dan dikuasai oleh siswa, serta contoh yang telah dijadikan materi tes kemampuan membaca nyaring.

Hasil di atas memperlihatkan bahwa kemampuan siswa kelas VIII.C SMP Negeri 10 Kota Palopo dalam membaca nyaring melalui model pembelajaran pair check dapat dikatakan tidak mampu. Hal ini dikarenakan adanya keterbatasan waktu, sehingga masih banyak siswa yang tidak menguasai aspek membaca nyaring dan langkah-langkah membaca nyaring melalui model pembelajaran pair check. Hal tersebut sejalan dengan pendapat Huda (2015:212) yang menyatakan bahwa model pembelajaran pair check memiliki kelemahan, yaitu membutuhkan waktu yang benar-benar memadai dan membutuhkan kesiapan siswa untuk menjadi pelatih dan partner yang jujur dan memahami soal dengan baik.

Hasil penelitian ini tidak sejalan dengan penelitian terdahulu yang dilakukan oleh Yuliariska dkk., (2016) dengan judul "Penerapan Model Pair Check untuk Meningkatkan Hasil Belajar IPA Siswa Kelas IV SDN 2 Manggissari Tahun Pelajaran 2015/2016". Penelitian ini bertujuan untuk mengetahui penerapan model pair check untuk meningkatkan hasil belajar IPA siswa kelas IV SDN 2 Manggissari tahun pelajaran 2015/2016. Hasil penelitian menunjukkan bahwa terjadi peningkatan hasil belajar siswa sebesar 10 dari rata-rata 74 pada siklus I menjadi 84 pada siklus II. Persaman penelitian ini dengan penelitian sebelumnya adalah sama-sama menggunakan model pembelajaran pair check, sedangkan perbedaan penelitian ini dengan penelitian sebelumnya adalah penelitian sebelumnya menerapkan model pembelajaran pada mata pembelajaran IPA. 


\section{Kesimpulan}

Hasil penelitian menunjukkan bahwa nilai rata-rata yang diperoleh siswa kelas VIII.C SMP Negeri 10 Kota Palopo dalam membaca nyaring melalui model pembelajaran pair check, yaitu 66,67 . Nilai rata-rata tersebut diperoleh dari sampel yang mendapat nilai 89 berjumlah $1(6,7 \%)$; sampel yang mendapat nilai 72 berjumlah $4(26,7 \%)$; sampel yang mendapat nilai 67 berjumlah 4 (26,7\%); sampel yang mendapat nilai 61 berjumlah 5 (33,3\%); sampel yang mendapat nilai 61 berjumlah $1(6,7 \%)$. Apabila dikonfirmasikan dengan KKM, maka kemampuan membaca nyaring melalui model pembelajaran pair check siswa kelas VIII.C SMP Negeri 10 Kota Palopo, yaitu yang mendapat nilai 77 ke atas sebanyak 1 sampel (6,7\%), sedangkan yang mendapat nilai di bawah 77 sebanyak 14 sampel (93,3\%). Dilihat dari tolok ukur kemampuan, siswa dapat dikatakan tidak mampu karena siswa yang memperoleh nilai di bawah 77 mencapai lebih dari 85\%.

\section{Ucapan Terima Kasih}

\section{Referensi}

Arikunto, 2006. Prosedur Penelitian Suatu Pendekatan Praktik. Jakarta: Rineka Cipta.

Arikunto, S. 2008. Metodologi Penelitian. Yogyakarta: Bina Aksara.

Chaer, A. 1994. Linguistik Umum. Jakarta: Rineka Cipta.

Dalman. 2014. Keterampilan Membaca. Jakarta: Rajagrafindo Persada.

Djumingin, S. 2015. Penilaian Pembelajaran Bahasa dan Sastra Indonesia Teori dan Penerapannya. Makassar: Badan Penerbit UNM.

Huda, M. 2015. Model-model Pengajaran dan Pembelajaran. Yogyakarta: Pustaka Pelajar. Phoenix, Tim Pustaka. 2013. Kamus Besar Bahasa Indonesia. Jakarta: Pustaka Phoenix.

Rahim, Farida. 2005. Pengajaran Membaca di Sekolah Dasar. Jakarta: Bumi Aksara.

Rusman. 2010. Model-Model Pembelajaran. Bandung: Rajawali Pers.

Solihatin, E., dan Raharjo. 2005. Cooperative Learning. Jakarta: Bumi Aksara.

Sugiyono. 2007. Metode Penelitian Kuantitatif, Kualitatif dan $R \& D$. Bandung: Alfabeta.

Sugiyono. 2014. Metode Penelitian Pendidikan (Pendekatan Kuantitatif, Kualitatif, dan R\&D). Bandung: Alfabeta.

Suprijono, A. 2013. Cooperative Learning Teori \& Aplikasi Paikem. Yogyakarta: Pustaka Pelajar.

Tarigan, H. G. 2008. Membaca sebagai Suatu Keterampilan Berbahasa. Bandung: Angkasa.

Tiro, M. A. 2008. Dasar-Dasar Statistika. Edisi Ketiga. Makassar: Andira Publisher.

Yuliariska dkk. 2016. Penerapan Model Pair Check untuk Meningkatkan Hasil Belajar IPA Siswa Kelas IV SDN 2 Manggissari Tahun Pelajaran 2015/2016. Jurnal PGSD Universitas Pendidikan Ganesha, 4(1). 